Gunnar Andersson, Turid Noack

\title{
Legal advances and demographic developments of same-sex unions in Scandinavia
}

\section{Rechtliche Fortschritte und demographische Entwicklungen bei den gleichgeschlechtlichen Lebensgemeinschaften in Skandinavien}

\begin{abstract}
:
In 2009, Norway and Sweden completed their process of granting same-sex couples the same rights to marriage as those granted to couples of opposite sexes. Following the introduction of a specific civil status for couples of the same sex, the registered partnership, in 1993 and 1995, both countries adopted fully gender-neutral marriage legislation in 2009. In the present article, we describe the road to gender-neutral marriage in Scandinavia and map out some of the demographic developments of same-sex partnerships and marriages. We demonstrate a recent switch to higher female than male same-sex union formation, and also a higher level of female than male same-sex marriage dissolution. These demographic patterns are similar across all countries of Scandinavia: Denmark, Norway, and Sweden.
\end{abstract}

Key words: same-sex marriage, registered partnership, family dynamics, Denmark, Norway, Sweden

\begin{abstract}
Zusammenfassung:
Im Jahre 2009 schlossen Norwegen und Schweden das Gesetzgebungsverfahren, das gleichgeschlechtlichen Paare die gleiche Rechte auf Heirat wie gegengeschlechtlichen Paaren gewährte, ab. Im Gefolge der Einführung einer besonderen Zivilstandes für gleichgeschlechtliche Paare, die registrierte Partnerschaft in den Jahren 1993 bzw. 1995, führten beide Länder im Jahre 2009 eine vollkommen geschlechtsneutrale Ehegesetzgebung ein. Im vorliegenden Beitrag beschrieben wir den Weg zur geschlechtsneutralen EheschlieBung in Skandinavien und stellen einige demographische Entwicklungen hinsichtlich gleichgeschlechtlicher Partnerschaft und Eheschließung dar. Wir zeigen auf, dass es in der letzten Zeit zu einer Trendwende kam: gleichgeschlechtliche Partnerschaften werden nun häufiger zwischen weiblichen als zwischen männlichen Partnern gegründet und dass die Trennungs-/Scheidungsrate unter weiblichen Partnerinnen höher ist als zwischen männlichen Partnern. Diese demographischen Muster sind über die drei skandinavischen Länder - Dänemark, Norwegen und Schweden hinweg einander ähnlich.
\end{abstract}

Schlagwörter: gleichgeschlechtliche Ehe, registrierte Partnerschaft, Dänemark, Norwegen, Schweden 


\section{Introduction}

In 1989, Denmark was the first country in the world to grant legal recognition to partners of the same sex. It introduced a new civil status, registered partnership, which was different in name but otherwise similar in contents to that of heterosexual marriage. Norway and Sweden followed the example of Denmark during the mid-1990s. In terms of legal rights and social practice, the registered partnership in the three Scandinavian countries amounted to a de facto same-sex marriage. This paved the way to discuss as well the adjustment of the marital codes to have them formulated in a truly gender-neutral manner. In 2009, Norway and Sweden completed their processes of granting same-sex couples the same rights to marriage as those granted to couples of opposite sexes: both countries then adopted fully gender-neutral marriage legislations. In the present article, we describe these developments and map out some of the demographic characteristics of same-sex partnerships and marriages in Scandinavia.

\section{Background: The legislation of same-sex unions in Scandinavia}

The issue of granting legal recognition to same-sex couples is high on the political agenda in many countries in different parts of the world. During the last decade, many countries have introduced legal recognition of same-sex unions, some with few legal consequences, but in an increasing number of countries the legal consequences are identical or nearly identical to those of opposite-sex marriages. Clearly, during the 1980s and 1990s the Nordic countries were forerunners to give same-sex couples the opportunity to legalise their unions on a nearly equal footing with that of opposite-sex marriages. However, in these countries the new legislations were first not incorporated into existing marriage acts. Instead, a new term, the registered partnership was invented and the countries passed separate acts on registered partnerships for same-sex couples. The first law was passed in Denmark in 1989. Norway was the second country to introduce this civil status in 1993 and the third country of Scandinavia, Sweden, followed suite in 1995. The two remaining Nordic countries, Iceland and Finland did the same in 1996 and 2002, respectively.

With a few exceptions, a registered partnership gave the same legal rights and duties as what a marriage provides to opposite-sex couples. The exceptions consisted of one or more of the following issues: the opportunity to jointly adopt a child, to have medically assisted insemination, the forms of how to solemnize the partnership, and requirements of legal residency in the country before entering partnership. These exceptions were, however, questioned and some of them also cancelled during subsequent years. For example, in 2003 registered partners in Sweden were allowed to jointly adopt a child and in 2005 in the same country medically assisted insemination was made available to women in registered partnerships. Already from the onset the procedures for dissolving a registered partnership were the same for registered partners as for opposite-sex spouses.

It was not by chance that the Nordic countries initially choose not to incorporate same-sex couples as a new category in existing marriage acts. One argument presented in the debates before the new laws were passed, was that modifying the existing marriage 
code might be perceived as a threat towards marriage as a social institution and its position in society. To avoid this kind of criticism, it seemed more sensible to propose a new term, i.e., the registered partnership, and a separate act for it. Once Denmark had come up with this solution, the other Nordic countries found it reasonable to adopt the same measure. Elsewhere in Europe, France met the same kind of arguments by introducing a new family form, the PACS, which was meant for opposite- and same-sex unions alike (Martin/Théry 2001). There was also a somewhat more pragmatic reason for having separate laws for same- and opposite-sex couples, as it was regarded easier to introduce a new law than to alter an existing one.

The public interest and debate surrounding the laws on registered partnerships was more or less intense in the different countries. The resistance to the legal recognition of same-sex unions seems to have been stronger in Norway than in Denmark. Traditionally, Denmark as well as Sweden have a reputation of being more socially liberal than Norway. A Danish study stressed that few politicians wanted to take on the burden of openly opposing the bill of registered partnerships (Søland 1998). In Sweden, this role was played by parliamentarians from a small Christian and an equally small right-wing populist party of that time. An analysis of the proceedings and debate prior to the passing of the Norwegian law indicated that parliamentarians had more accepting views on same-sex partnerships than the population at large (Halvorsen 1998; Størksen 2000). Opinion polls suggested that although a considerable proportion of the population at that time was indifferent, "there never seems to have been a general majority in favour of the Act" (Halvorsen 1998:213). Once the laws were introduced, hardly any voices have been heard in favour of abolishing the opportunity to form registered partnerships. Regarding lesbian and gay people themselves, the majority were strongly in favour of the law, but others were more neutral or even opposed to it. For example, many women with a background in lesbian feminism were not particularly enthusiastic about the possibility of acquiring the state's recognition of their relationships (Rydström 2004).

A few things stand out when one compares the debates on same-sex partnerships and marriage in Scandinavia to similar debates in other countries. First, the Nordic countries are strongly secular and political debates perceived as carried out with "rational" arguments. This gives little public room to religiously coloured arguments against same-sex marriage. However, within Scandinavia, there is relatively more scope for such arguments in Norway than in Denmark and Sweden. Second, Scandinavian culture values consensusseeking and keeps the value of social equality in high esteem. This reassures that once the ideal of equal rights regardless of people's sexual orientation is embraced one will hear less argument than in other countries against the principle of people's equal right to marry. After the introduction of the partnership laws, for example, controversies were more likely to arise on amendments related to same-sex couples' opportunity to adopt children than on the re-labelling of partnerships into full-fledged marriages. Again, controversies on the latter issue were stronger in Norway than in Sweden (see below).

In 2009, Norway and Sweden finally took the last step to make their marriage legislation gender neutral by introducing laws that cover same- and opposite-sex marriages alike. These laws came into force on January 1, 2010, in Norway and May 1, 2010, in Sweden. No new registered partnerships can be formed subsequent to these dates. Couples who had already entered a registered partnership may however retain their civil- 
status label as registered partners if they want to. If they prefer they can choose instead to convert their civil status to that of marriage. In both countries, this is mainly a symbolic act, as there are no longer any legal differences attached to the statuses of already registered partnerships and same-sex marriages. Later in 2010, the Icelandic parliament voted for the introduction of same-sex marriages in Iceland. Denmark and Finland have so far not enacted gender neutral marriage acts like those of Norway and Sweden.

As in the debate before enacting the partnership law, the Norwegian government's wish to introduce a gender neutral marriage act was discussed vividly in public. In the parliamentary vote, two thirds of parliamentarians voted for the new law, one third against it. According to different polls, the majority of people also seemed to be in favour of the law. Subsequent to its introduction, the small Christian People's Party decided that they will continue work towards repealing it. Most resistance then came from minority groups of Christians and Muslims. Another and more curious protest against the gender neutral law comes from a group of opposite-sex married people who claim that they have married according to another marriage act than the present gender neutral one, and want to still be married according to the old law. Their argumentation seems to be based purely on principle, as no practical consequences of such a distinction can be claimed.

In Sweden, all political parties save one, the small Christian Democrats Party, had been clearly in favour of a gender neutral marriage law already before 2009. The introduction of the new law was delayed mainly as the centre-right government aimed at a consensus that could also involve the Christian Democrats. These attempts failed and the parliamentary vote produced an overwhelming majority in favour of the new law with more than nine out of ten votes supporting it. Subsequent to its introduction the debate switched arena to that of the Swedish (Lutheran) State Church. This church has the right to solemnize marriages on behalf of the state and the question was whether it should cede this right in order to not have to deal with same-sex marriages. In a vote at the church meeting in October 2009, the clergy instead voted in favour of embracing same-sex marriages into its realm.

\section{The first step: Registered partnerships}

With the legal recognition of registered partnerships several new categories were added to the civil-status systems of the Scandinavian countries, i.e., those of registered partner, divorced partner, separated partner (Norway), and surviving partner. Despite many similarities in population-registration systems and the organization of Statistical Central Bureaus, published statistics on registered partnerships in Scandinavia are still not entirely comparable across countries. Before 1999, Statistics Denmark only produced statistics on stocks of people in partnerships but no vital statistics on newly formed or dissolved partnerships. Available statistics on flows, i.e., on changes in civil status during a calendar year, differ too. Statistics Denmark (from 1999 onwards) and Statistics Norway produce statistics on newly registered partnerships, i.e., on couples, while Statistics Sweden produce data on individuals and individual changes in civil status during a year.

As already pointed out, Denmark is the country in the world with the longest experience of de facto same-sex marriages, by the name of registered partnerships. As a Nordic 
country, it has a strong tradition of maintaining an accurate and reliable populationregistration system. With the access to a database with individual-level data extracted from the Danish population registers, we have the opportunity to produce and present some data on selected socio-demographic characteristics of registered partners in Denmark. (For similar information on Norway and Sweden, see Andersson et al. 2006). Table 1 provides a summary of a few key characteristics of registered partners in Denmark in partnerships formed during 1989-2002. As a comparison, we also offer the corresponding data on spouses in opposite-sex marriages formed during the same calendar period. The statistics refer to the total person-months of married people during October 1989 to December 2002, with new partnerships and marriages added on a monthly basis and unions followed until divorce, emigration, the death of a partner, or the end of 2002, whichever comes first. We have computed these statistics from individual data on spouses and registered partners born in Denmark in 1945 and later.

Table 1: Demographic characteristics of registered partners and opposite-sex spouses in Denmark, 1989-2002. Percent

\begin{tabular}{|c|c|c|c|c|}
\hline & $\begin{array}{c}\text { Same-sex } \\
\text { Men }\end{array}$ & $\begin{array}{l}\text { Same-sex } \\
\text { Women }\end{array}$ & $\begin{array}{l}\text { Opposite-sex } \\
\text { Men }\end{array}$ & $\begin{array}{l}\text { Opposite-sex } \\
\text { Women }\end{array}$ \\
\hline \multicolumn{5}{|l|}{ Age at marriage } \\
\hline $16-22$ & 3 & 2 & 3 & 7 \\
\hline $23-29$ & 19 & 21 & 39 & 48 \\
\hline $30-39$ & 45 & 46 & 42 & 33 \\
\hline $40-57$ & 33 & 31 & 16 & 12 \\
\hline \multicolumn{5}{|l|}{ Residence } \\
\hline Greater Copenhagen & 56 & 45 & 21 & 21 \\
\hline \multicolumn{5}{|l|}{ Parenthood } \\
\hline Premarital childbearing & 9 & 19 & 56 & 58 \\
\hline \multicolumn{5}{|l|}{ Educational level } \\
\hline Primary & 21 & 20 & 22 & 23 \\
\hline Secondary & 48 & 31 & 52 & 47 \\
\hline Tertiary & 31 & 49 & 26 & 29 \\
\hline $\mathbf{N}$ & 2,962 & 2,407 & 370,845 & 381,246 \\
\hline Person months & 358,000 & 256,000 & $50,256,000$ & $52,039,000$ \\
\hline
\end{tabular}

Note: Calculations based on partners and spouses born in Denmark in 1945 onwards; percentages refer to fractions of exposure time in union in 1989-2002 of partnerships and marriages formed during October 1989-December 2002.

Source: Population-register data of Statistics Denmark, authors' own calculations.

First, we note that registered partners in 1989-2002 were older than newly married heterosexual people. This is perhaps not surprising as gay and lesbian people previously had no opportunity to manifest any union commitment of theirs in a formal civil status. If our data had not been limited to cohorts born in 1945 and later, the fractions of registered partners in the highest age bracket had been even higher. Second, same-sex couples are strongly over-represented in the metropolitan area of Copenhagen. Third, about 9 percent of male partners and 19 percent of female partners were parents when entering their partnership. In most cases, this status stems from children born in a previous heterosexual 
union. Premarital childbearing is even more common among heterosexual spouses, since the majority of people in Denmark are parents at the time of marriage formation. In this case, however, the children born prior to marriage typically are joint children of the two spouses. Finally, same-sex partners have a somewhat higher educational attainment than opposite-sex spouses. In particular, this holds for female registered partners. The statistics on registered partners in Denmark very much resemble previously published statistics on registered partnerships in Norway and Sweden (see Andersson et al. 2006).

\section{Trends in registered partnerships in Scandinavia}

Table 2 provides an overview of the aggregate number of new partnerships (Denmark, Norway) and newly registered partners (Sweden) in Scandinavia since the introduction of the new civil status. Data are provided separately for women and men. They come from official statistics and are, as already pointed out, not totally comparable with each other: in Sweden published vital statistics always refer to individuals (with residence in Sweden), for Denmark and Norway they refer instead to unions (with at least one partner with legal residence in the country). Furthermore, no official data on new partnerships are available for Denmark during 1989-1998. The statistics still demonstrate the key components of trends in registered partnerships in Scandinavia. For example, the data for Norway and Sweden show a spike in partnership registration in the first year when the new partnership laws were enacted (i.e., the Norwegian partnership law became effective on August 1, 1993; the Swedish law came into force on January 1, 1995). In both countries, a vast majority of these pioneering partners were men. Partnership registration then levelled off, but in more recent years all three countries witness increasing trends in partnership registration. Norway experienced a minor drop in partnership registration in 2008, which likely was caused by the announcement in that year of the possibility to enter formal marriage the following year. Finally, a very interesting development in all three countries is a turnaround in the gender composition of newly formed partnerships. In recent years, the majority of new partnerships consist of two women. Figure 1 provides an example of these developments, where we let data from Sweden highlight the general trends in partnership formation in Scandinavia. 
Table 2: Newly registered partnerships (couples) in Denmark and Norway and newly registered partners (individuals) in Sweden, by calendar year

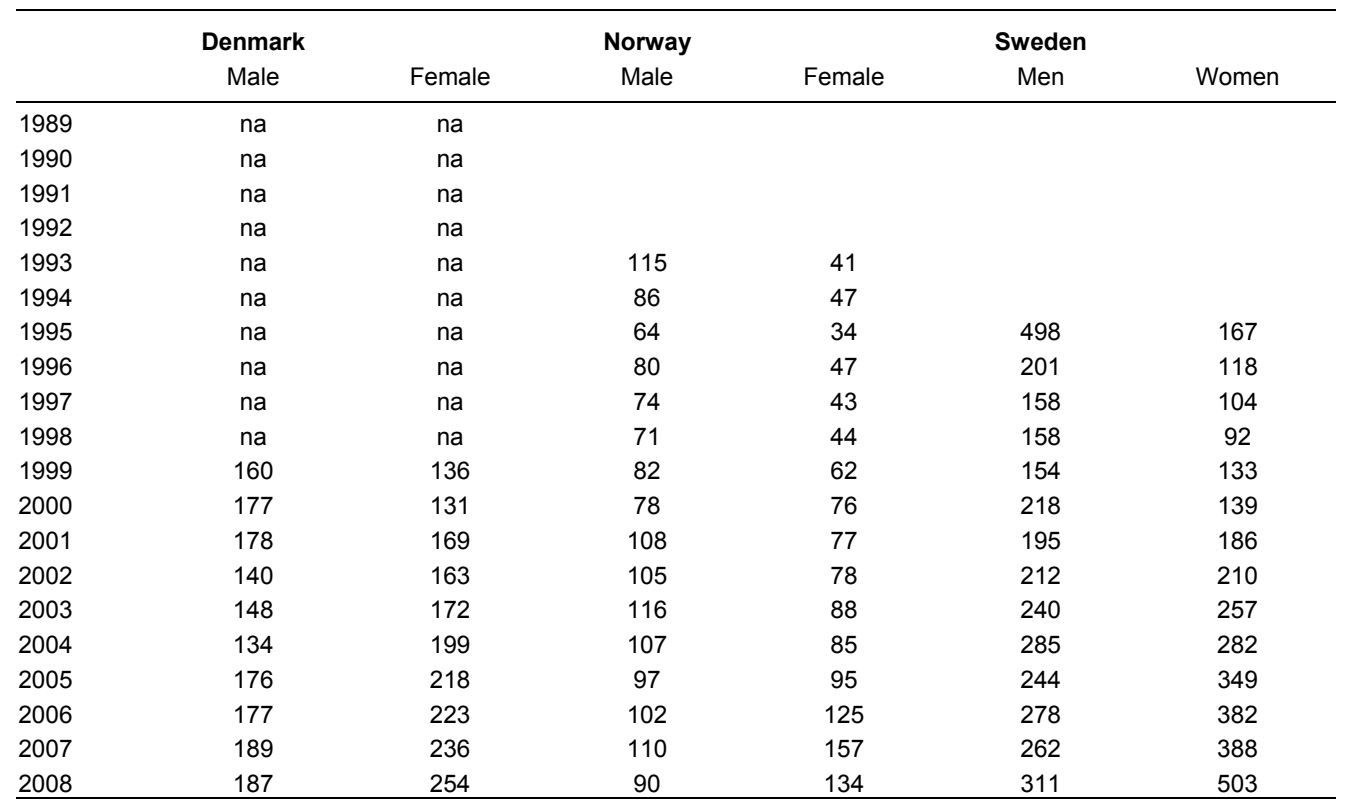

na $=$ not available in official statistics

Source: Statistics Denmark, Statistics Norway, and Statistics Sweden

Figure 1: Newly registered partners in Sweden, 1995-2008, by sex

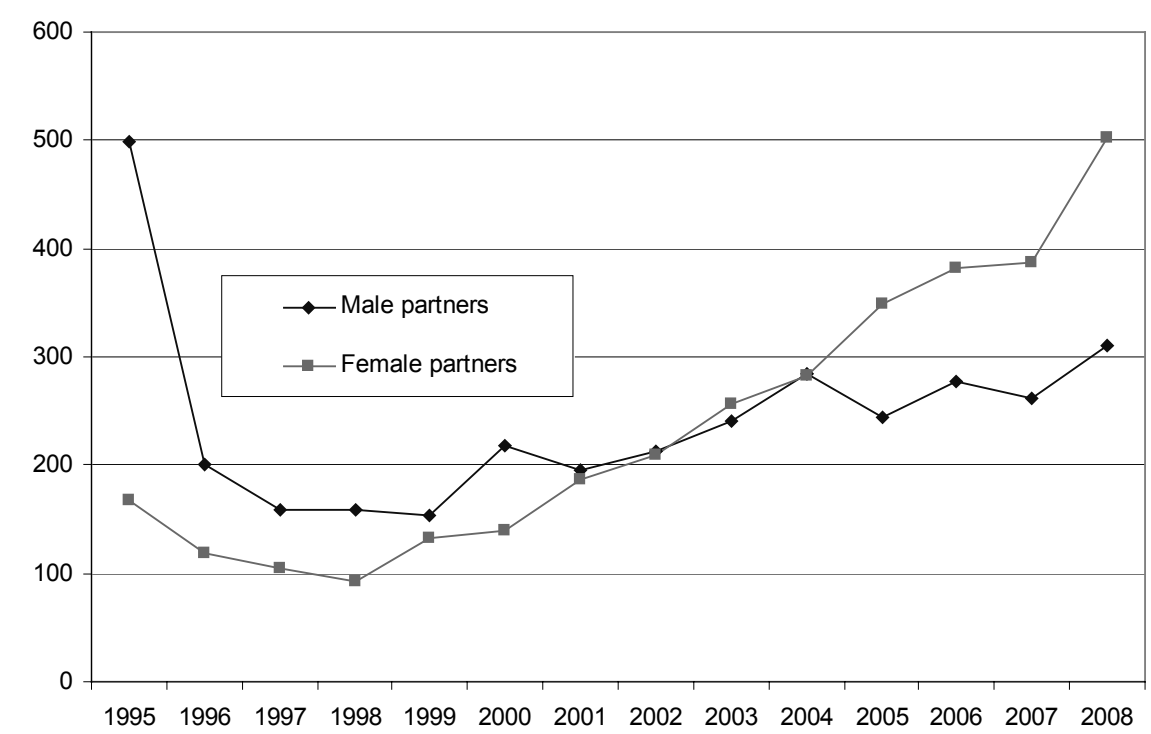

Source: Statistics Sweden 


\section{Divorce risks in registered partnerships in Scandinavia}

Our access to longitudinal and all-encompassing population-register data and the existence of a unique civil status for same-sex unions in Scandinavia allow us to calculate divorce risks for registered partners. Andersson et al. (2006) provide an account of patterns in divorce risks in registered partnerships in Norway and Sweden. They show that various socio-economic characteristics of partners have a rather similar association with divorce risks in same-sex marriages as in opposite-sex marriages. For example, higher age is clearly related to lower divorce risk in any type of union. Table 3 presents patterns in divorce risks in registered partnerships in Denmark. They are calculated for the populations presented in Table 1 and cover the behaviour during 1989-2002. As a comparison, divorce risks are calculated as well for spouses in opposite-sex marriages during the same calendar period. Our calculations for Denmark cover a more extended calendar period and a larger number of observations than those of the previous study for Norway and Sweden. This should guarantee that estimated risk patterns are less exposed to the possible role of random variation than in the previous study. Divorce risks stem from a multivariate eventhistory model of the hazard of divorce (for an introduction to this method, see Allison 1984). Relative risks are calculated for our available socio-demographic variables and indicate the effects on divorce of any level of a certain covariate relative to a baseline category of the same covariate. A risk of, say, 0.60 indicates that the standardized divorce risk for that category is 40 percent lower than for partners belonging to the reference category $($ risk $=1)$ of the same variable (for terminology, see Hoem 1993).

Table 3 shows, for example, that the age gradient in divorce risk runs in the same direction but is somewhat stronger for same-sex partners than for opposite-sex spouses. Furthermore, residence in the capital area is related to elevated divorce risks and a higher educational attainment to lower disruption risks for same- and opposite-sex unions alike. Patterns for male and female registered partners are quite similar, too. However, the divorce-stimulating effect of being a parent prior to partnership formation is much stronger for male registered partners than for other spouses. We also notice a slight difference in the period trends in divorce risks for male and female registered partners: divorce risks seem to have increased over calendar time for male unions and decreased for female same-sex unions.

Figure 2 provides information on how the levels of divorce risks differ between male and female partnerships in each of the three countries of Scandinavia. Our calculations for Denmark involve the data and covariates presented in Table 3; the relative risks for Norway and Sweden stem from Andersson et al. (2006) and involve a slightly different data structure and setup of covariates. Nevertheless, our comparison shows that in each country the divorce risk is much higher in unions of two women than in those of two men. In Norway and Sweden, divorce risks in female partnerships are more than twice those in male partnerships. In Denmark, this difference is smaller but the divorce risk in partnerships of two women is still more than 50\% higher than the corresponding risk in unions of two men. Perhaps the longer observation period for Denmark and the fact that period trends in divorce risks have been converging (Table 3) produce the more moderate difference in divorce risks between male and female registered partners in this country. Finally, a comparison with divorce-risk levels in opposite-sex marriages reveals that in Sweden it 
is on par with the divorce risk in partnerships of two men (Andersson et al. 2006) while in Denmark the risk in a heterosexual union is lower still (not shown).

Table 3: Relative divorce risks of registered partners and opposite-sex spouses in Denmark, 1989-2002, by socio-demographic characteristics

\begin{tabular}{lcccc}
\hline & $\begin{array}{c}\text { Same-sex } \\
\text { Men }\end{array}$ & $\begin{array}{c}\text { Same-sex } \\
\text { Women }\end{array}$ & $\begin{array}{c}\text { Opposite-sex } \\
\text { Men }\end{array}$ & $\begin{array}{c}\text { Opposite-sex } \\
\text { Women }\end{array}$ \\
\hline Age at marriage & 1 & & & \\
$16-22$ & 0.50 & 0.61 & 0.62 & 0.57 \\
$23-29$ & 0.28 & 0.31 & 0.53 & 0.47 \\
$30-39$ & 0.15 & 0.20 & 0.53 & 0.42 \\
$40-57$ & & & & \\
Residence & 1 & 1 & 1 & 1 \\
Greater Copenhagen & 0.73 & 0.86 & 0.74 & 0.68 \\
Non-metropolitan Denmark & & & & \\
Parenthood & 1 & 1 & 1 & 1 \\
No premarital childbearing & 2.32 & 1.28 & 1.03 & 1.12 \\
Premarital childbearing & & & & \\
Educational level & 1 & 1 & 1 & 1 \\
Primary & 0.80 & 0.68 & 0.62 & 0.58 \\
Secondary & 0.58 & 0.43 & 0.41 & 0.40 \\
Tertiary & & & & \\
Calendar period & 1 & 1 & 1 & 1 \\
1989-1995 & 1.13 & 0.86 & 1.03 & 1.03 \\
1996-2002 & 2,962 & 2,407 & 370,845 & 381,246 \\
N & 358,000 & 256,000 & $50,256,000$ & $52,039,000$ \\
Person months & 529 & 43,338 & 514 & 46,733 \\
Divorces & & & & \\
\hline Note: Calculation & & & & \\
& & & & \\
\end{tabular}

Note: Calculations based on partners and spouses born in Denmark in 1945 onwards; relative risks apply to partners and spouses in partnerships and marriages formed during October 1989-December 2002; risks are standardized for duration of partnership/marriage.

Source: Population-register data of Statistics Denmark, authors' own calculations. 
Figure 2: Divorce risks of female registered partners vs male registered partners, Denmark 1989-2002, Norway 1993-2001, and Sweden 1995-2002.

Separate calculations for each country.

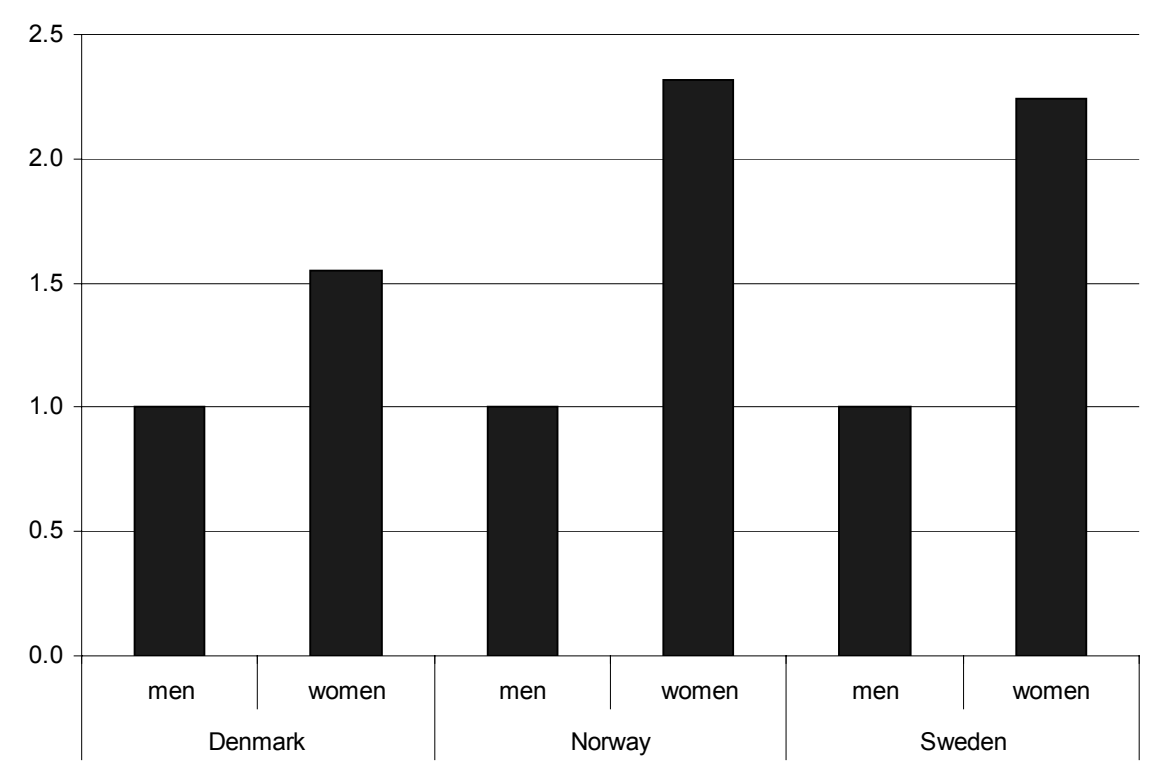

Note: Relative divorce risks are standardized for the impact of socio-demographic variables (see Table 3 above and Tables 3 and 4 in Andersson et al. 2006).

Source: Population-register data of Statistics Denmark, Statistics Norway, and Statistics Sweden, authors' own calculations.

\section{From registered partnership to same-sex marriage}

At the time of producing this text, the new marriage acts of Norway and Sweden were so fresh that not much could be said about conversions of registered partnerships into marriages or on newly formed same-sex marriages during their first year of existence. Still, it may be worth looking at some very first monthly statistics produced by Statistics Norway and Statistics Sweden on these issues.

As mentioned before, there is no legal difference between being registered partner and being married; to convert a registered partnership into a marriage is a rather simple procedure. After slightly more than half a year of observation, we note that although a sizeable fraction of existing partners have converted their civil status into formal marriage, the majority has not changed civil status. After nine months with the new law, the conversion rate in Norway was 31 out of 100 partnerships. Female partners were more active than men in partnership conversions, with 36 of 100 female partnerships and 26 out of 100 male partnerships being turned into marriages. In Sweden after seven months, the conversion rates were much lower, with $15 \%$ of partners having changed civil status and 
no visible difference between women and men. In Norway, the conversion rate was highest among partners in their 30s and lowest among the youngest registered partners.

As regards entirely new same-sex marriages formed during 2009, there were 239 new marriages in Norway during January to October and 310 new marriages in Sweden during May to November. In both countries a majority of these spouses, 63 and 65 percent, were female, which strengthens the recent trend of increasing female dominance of Scandinavian same-sex marriage formation. Finally, the monthly rates of same-sex marriage formation during 2009 were visibly higher than the corresponding rates of partnership formation during preceding years.

A comparison with statistics on heterosexual marriage formation during the same brief periods suggests that around one percent of new marriages were same-sex marriages (Norway 1.1\%; Sweden $0.9 \%$ ). This is a higher fraction than those of the period of registered partnerships (see Andersson et al. 2006). It remains to be seen whether this new level constitutes a trend change or rather a short-term phenomena triggered by the longawaited possibility to acquire a more preferred civil status (see also Noack et al. 2005).

\section{Same-sex unions with children}

If the 1990s brought the legal recognition of same-sex partnerships in Scandinavia then the 2000s brought a trend of increasing prevalence of parenthood in same-sex unions. During the 1990s childrearing and childbearing in same-sex partnerships was still relatively uncommon even though many registered partners had a child from a previous heterosexual union (e.g., Table 3). In Sweden, for example, the number of children who live in same-sex partnership families has increased from less than 70 at the end of the 1990s to 749 at the end of 2008 (Karlsson 2009). In Norway, the same number increased from 46 in 2001 to 256 in 2009. Most of these children live in a partnership/marriage of two women. In Sweden, only 6\% of them live in a family with two fathers. Accordingly, parenthood has become a quite common experience in families headed by two women; close to $40 \%$ of female same-sex partnerships/marriages in Sweden now contain co-resident children. About half of these children are less than four years old, which reflects another important trend, i.e., that of increasing childbearing in same-sex unions. With more liberal attitudes to same-sex parenting and the liberalization of laws concerning adoption of children and insemination of women in registered partnerships it has become much more common to become a parent while living in a same-sex marriage. The number of children born in partnership families in Norway, for example, increased from only five in 2001 to 72 in 2008 (Figure 3). 
Figure 3: Number of children born to registered partners in Norway, 1998-2008

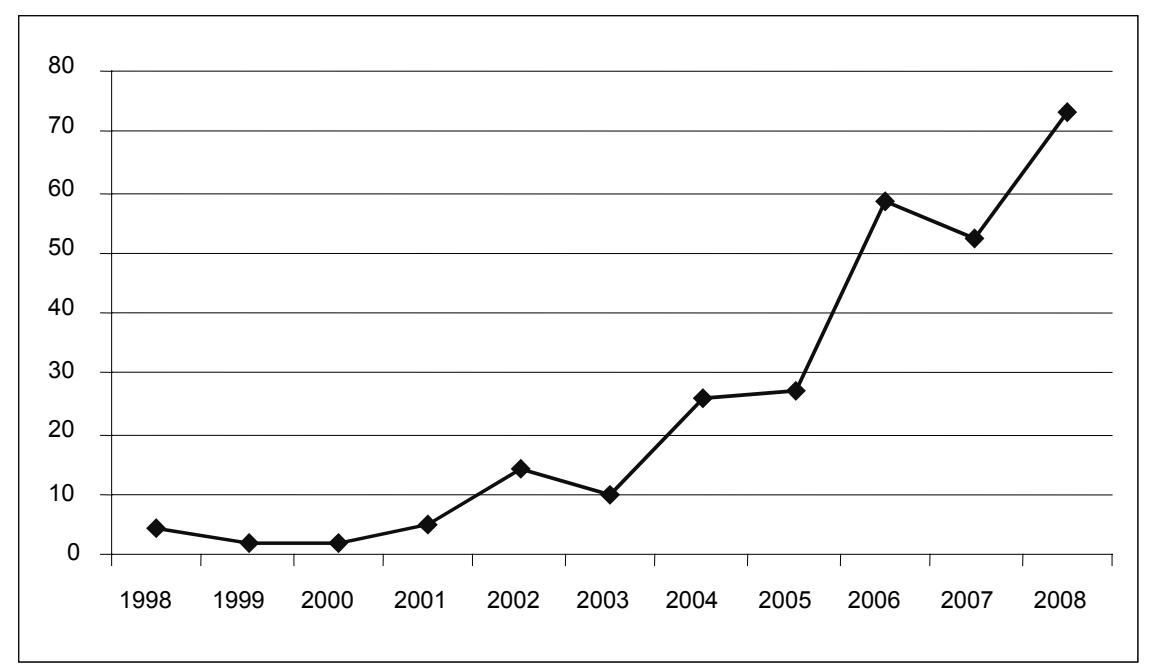

Source: Statistics Norway

The upsurge in childrearing and childbearing in same-sex unions has not gone unnoticed. In Scandinavia, like in many other parts of Europe, same-sex parenting initially appeared to be a more controversial issue than that of the legal recognition of same-sex unions. We note that the social acceptance and legal recognition of same-sex partnerships in Scandinavia paved the way to the social recognition of same-sex parenting, rather than the other way around. This is quite contrary to the situation in the U.S. where same-sex marriage is a much more controversial issue than same-sex parenting (Cherlin 2009).

\section{Summary and discussion}

In 2009, the journey in Norway and Sweden towards equal rights for same-sex and opposite-sex couples to marry, live as married, and to divorce was completed. It begun some one and a half decades earlier with the introduction of these countries' partnership laws. The registered partnership amounted to a de facto same-sex marriage, the laws in 2009 made same-sex and opposite-sex marriages equal also on formal grounds. In our review of developments, we have described how various controversies in Scandinavia on issues related to same-sex marriage have been vivid but still much less heated than in, for example, the U.S. In Scandinavia, marriage seems to be less culturally important and the status of marriage in society less ideologically divisive than in America (Cherlin 2009) and some parts of Europe. The absence of introduction of formal same-sex marriages in Denmark, the country which first introduced the registered partnership, partly supports this observation. To some extent, the lack of continued progress in this country stems less from the strong resistance towards same-sex marriage than from the lack of enthusiasm from those who would enjoy it. 
At the international arena, Scandinavia clearly has played the role of forerunner in the granting of equal rights to couples of different sex-compositions to marry. In the American debate, it has sometimes been argued that these developments have also undermined the status of heterosexual marriage and led to the erosion of marriage in Scandinavia (e.g., Kurtz 2004). An inspection of trends in heterosexual marriage formation in the Nordic countries gives no support to such an interpretation. On the contrary, both Denmark and Sweden witness clear reversals from stable or decreasing to increasing trends in marriage formation subsequent to the introduction of these countries' partnership laws (Figure 4, see also Ohlsson 2009). Similar short-term or long-term reversals in the same direction can be observed for Norway, Iceland and Finland shortly after the introduction of the partnership laws in these countries (see Andersson et al. 2010). If anything, the democratization of marriage seems to have made this institution more, not less popular.

Figure 4: Total First Marriage Rate of Denmark and Sweden, 1965-2004

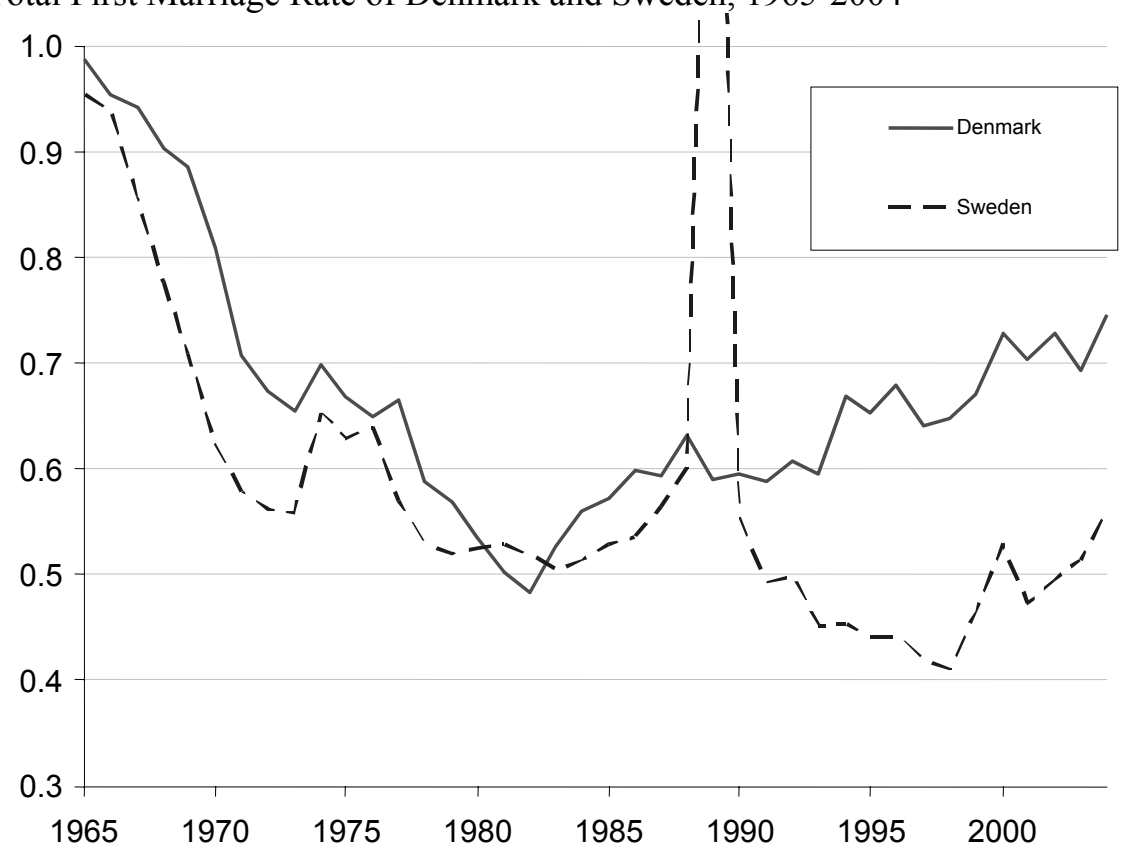

Note: Trends in marriage formation in Sweden show a temporary and distinct deviation from their longterm developments in 1989. The TFMR in that year has the unrealistic value of 1.51, implying that 151 percent of women would marry if the marriage rates of that year had prevailed. The upsurge in marriage formation was due to the abolishment of any widow's pensions for people married after that year, see Hoem 1991.

Source: Council of Europe (2006)

In demographic terms we reported on an increasing femininization of the dynamics of same-sex marriages in Scandinavia. In recent years, women have become more prone than men to enter same-sex partnerships and marriages. Furthermore, they are much more 
prone to divorce than male partners are. These observations are interesting for demographers in general, as they shed new light on the gendered dimensions of family dynamics. Previous research shows that cohabiting heterosexual women more often than their partners report intentions to marry. Once married, heterosexual women are often also more likely than men to initiate a divorce (e.g., Brinig and Allen 2000, Kalmijn and Poortman 2006). Interestingly, the presence of two women in a couple supports these tendencies of elevated activity in terms of family dynamics.

Another new demographic trend for same-sex families in Scandinavia is the increasing prevalence of childbearing and parenthood. In Sweden, the number of children who live in same-sex partnership families has increased ten-fold over the last ten years, albeit from a low level (Karlsson 2009). The developments for Norway are similar and contain strong increases both in the number of partnership families with children and children born into registered partnerships. Most of these families are run by two women. The increasing prevalence and social acceptance of parenthood in same-sex unions can be regarded as one aspect of the increasing integration of Scandinavian same-sex families into main-stream society. As opportunities for parenthood is stronger for women than for men, this may also strengthen and partly drive the trend of increasing feminization of same-sex marriage formation.

\section{Acknowledgements}

We are grateful to Jørn K. Pedersen of Statistics Denmark for having prepared the individual-level civil-status data on spouses and partners in Denmark. We thank Therese Karlsson of Statistics Sweden and Kirsten Enger Dybendal of Statistics Norway for updates on monthly data on marriage formation in 2009. Gunnar Andersson gratefully acknowledges financial support from Vetenskapsrådet via the Stockholm University Linnaeus Center on Social Policy and Family Dynamics in Europe, SPaDE, and the Swedish Initiative for research on Microdata in the Social and Medical Sciences, SIMSAM. Finally, we are grateful for helpful comments from Sofi Ohlsson, Gerda Neyer and the editors of Zeitschrift für Familienforschung/Journal of Family Research.

\section{References}

Allison, Paul (1984): Event history analysis: Regression for longitudinal event data. Beverly Hills, CA: Sage.

Andersson, Gunnar/Noack, Turid/Seierstad, Ane/Weedon-Fekjær, Harald (2006): The demographics of same-sex marriages in Norway and Sweden. Demography, 43 (1), pp. 79-98.

Andersson, Gunnar/Ohlsson, Sofi/Eriksson Helen/Carlsson, Johan/Persson, Lotta (2010): Family forerunners: Family dynamics in the Nordic countries. Stockholm: Stockholm University Demography Unit (working paper).

Brinig, Margaret/Allen, Douglas (2000): These boots are made for walking: Why most divorce filers are women. In: American Law and Economics Review, 2, pp. 126-169.

Cherlin, Andrew (2009): The marriage-go-round: The state of marriage and the family in America today. New York: Alfred Knopf. 
Council of Europe (2006): Recent demographic developments in Europe 2005. Strasbourg: Council of Europe Publishing.

Halvorsen, Rune (1998): The ambiguity of lesbian and gay marriages: Change and continuity in the symbolic order. In: Löfström, Jan (Ed.): Scandinavian homosexualities: Essays on gay and lesbian studies. New York: Harrington Park Press, pp. 207-231.

Hoem, Jan M. (1993): Classical demographic methods of analysis and modern event-history techniques. In: IUSSP (Ed.): 22nd International Population Conference, Montreal, Canada, Vol. 3, pp. 281-291.

Hoem, Jan M. (1991): To marry, just in case...: The Swedish widow's-pension reform and the peak in marriages in December 1989. In: Acta Sociologica, 34, pp. 127-135.

Kalmijn, Matthijs/Poortman, Anne-Rigt (2006): His and her divorce: The gendered nature of divorce and its determinants. In: European Sociological Review, 22 (2), pp. 201-214.

Karlsson, Therese (2009): Fler kvinnor gifter sig. In: Välfärd, 3, 2009, p. 20.

Kurtz, Stanley (2004): The end of marriage in Scandinavia: The "conservative case" for same-sex marriage collapses. In: The Weekly Standard, Vol. 9, No 20.

Martin, Claude/Théry, Irène (2001): The PACS and marriage and cohabitation in France. In: International Journal of Law, Policy and the Family, 15, pp. 135-158.

Noack, Turid/Seierstad, Ane/Weedon-Fekjær, Harald (2005): A demographic analysis of registered partnerships (Legal same-sex unions): The case of Norway. In: European Journal of Population, 21, pp. 89-109.

Ohlsson, Sofi (2009): Marriage in fashion? Trend reversal in marriage formation in Sweden. In: Stockholm Research Reports in Demography 2009, 7. Stockholm: Stockholm University.

Rydström, Jens (2004): From outlaw to in-law: On registered partnership for homosexuals in Scandinavia, its history and cultural implications. Paper presented to the conference "Same-sex couples, same-sex partnerships and homosexual marriages: A focus on cross-country differentials", Stockholm, September 25-26, 2003. Conference proceedings available as Documents de travail, 124, 2004. Paris: INED.

Størksen, Ingvill (2000): Homofili og politikk. En komparativ analyse av verdiendringer og meningskoalisjoner bak vedtaket om partnerskapsloven i Danmark og Norge. Bergen: Institutt for sammenlignende politikk, University of Bergen (thesis).

Søland, Birgitte (1998): A queer nation? The passage of the gay and lesbian partnership legislation in Denmark, 1989. In: Social Politics 5, (1), pp. 48-69. 
